\title{
非正弦波磁束下におけるアモルファス磁性材料の鉄損特性
}

\author{
学生員 堀 慎一朗* 正 員 原田 和郎* \\ 正員 石原 好之* 正員 戸高 敏之*
}

\section{A Study of the Loss Characteristics of the Amorphous Magnetic Material under the Non-sinusoidal Wave Magnetic Flux}

Shinichiro Hori*, Student Member, Kazurou Harada*, Member, Yoshiyuki Ishihara*, Member, Toshiyuki Todaka*, Member

This paper has investigated iron loss characteristics of amorphous magnetic materials under the non-sinusoidal wave magnetic flux. The iron loss characteristics of amorphous magnetic materials have been compared with grain-oriented magnetic steel sheet. The measurement of the iron loss has been carried out with SST. As a result, it is found that the increase ratio of the iron loss of the amorphous magnetic material under the excitation of distorted waveforms and symmetric PWM-waveforms is less than that of the grain-oriented magnetic steel sheet. On the other hand, it is found that the increase ratio of the iron loss of the amorphous magnetic material under the excitation of asymmetric PWM-waveforms is larger than that of the grain-oriented magnetic steel sheet.

キーワード : アモルファス磁性材料, 方向性電磁鋼板, 鉄損, 歪み波磁束, 対称 PWM 波, 非対称 PWM 波

Keywords : amorphous magnetic materials, grain-oriented magnetic steel sheet, iron loss, distorted waveforms, symmetric PWM-waveforms, asymmetric PWM-waveforms

\section{1. はじめに}

現在，変圧器の鉄心材料の多くは，方向性電磁鋼板が使 用されている。しかし近年，鉄心材料としてアモルファス 磁性材料を用いる事により更なる損失の低減が達成されて いる。変圧器などの電気機器の中で生じる磁束波形は, 巻 線に正弦波電圧が印加されても, 機器鉄心の部分的な磁束 波形は歪むため, 歪夕波磁束下での鉄損特性を知る必要が ある。また近年，パワーエレクトロニクス技術の発展によ り, モーターの制御やスイッチング電源に PWM インバータ が広く用いられている。アモルファス磁性材料及び方向性 電磁鋼板はモーターには使用されていないが，今後各種機 器の高周波駆動化に伴い, PWM 波による高調波が変圧器鉄 心に影響することが考えられ，PWM 波励磁下での鉄損特性 を知る必要があると考えられる。さらにスイッチングタイ ミングのずれにより, PWM 波形が非対称になる可能性があ る。波形が非対称になると, 直流成分及び偶数調波が重畳 してくる。アモルファス磁性材料の偶数調波の影響はまだ 検討されておらず，明確にしておく必要がある。

本論文では，方向性電磁鋼板とアモルファス磁性材料に

\footnotetext{
同志社大学工学部電気工学科

T610-0321 京田辺市多々羅都谷 1-3

Department of Electrical Engineering, Doshisha University

1-3, Tatara-Miyakodani, Kyotanabe 610-0321
}

ついて, 実機の変圧器に生じる波形に近い歪み波磁束下で の鉄損特性を測定し, 磁束正弦波条件との違いについて検 討した(1)。さらに, 対称 PWM 励磁下及び対称 PWM 波に直 流を重畳させた非対称 PWM 波形励磁下における鉄損特性 を明らかにした(2)。

\section{2. 測定方法}

〈2·1〉 歪み波作成方法 図 1 に示寸鉄心を用いて歪 み波を発生させる磁気回路を構成した。鉄心は磁路長の異 なる 2 つの方向性電磁鋼帯で作られたカットコアで構成し た。幾何学的平均磁路長はそれぞれ $671 \mathrm{~mm}$ と $471 \mathrm{~mm}$ で, 断面積は両方とも $800 \mathrm{~mm}^{2}$ である。

図 2 に本実験の測定系を示す。まず, 図 2 の励磁装置の 位置に図 1 の歪夕波磁束発生用鉄心を置き, 一次巻線に正 弦波を印加する。二つの二次巻線からは, 波形の異なる歪 み波が得られる。各磁路の磁束波形及び調波解析結果を図 3 に示す。高調波含有率にそれほど大きな変化は見られない が，各高調波の位相はそれぞれ逆相に入っており，この二 つの波形を足し合わせると正弦波になる。この波形をパソ コンにとり込み, 図 2 の励磁装置を単板磁気試験器 (SST) に置き変えて, 得られた歪み波により試料を励磁する。

〈2-2〉 PWM 波励磁 対称 PWM 波形は三角波と正弦 波の両波形瞬時值の大小関係から生成する ${ }^{(3)}$ 。本実験では単 


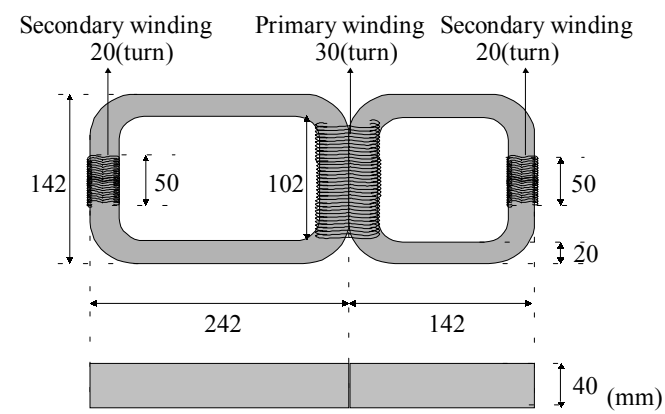

図 1 歪夕波磁束発生用鉄心

Fig. 1. Iron cores for distorted waveform generation.

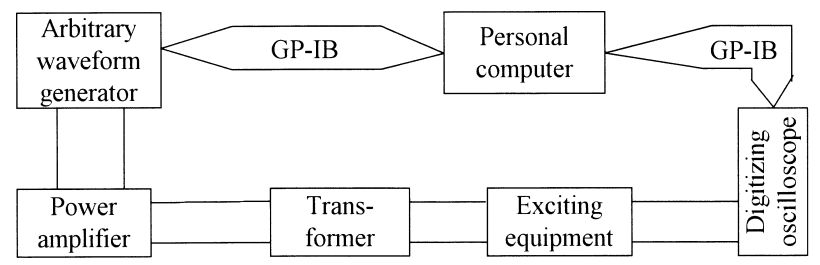

図 2 実験の測定系

Fig. 2. Block diagram of measurement system.
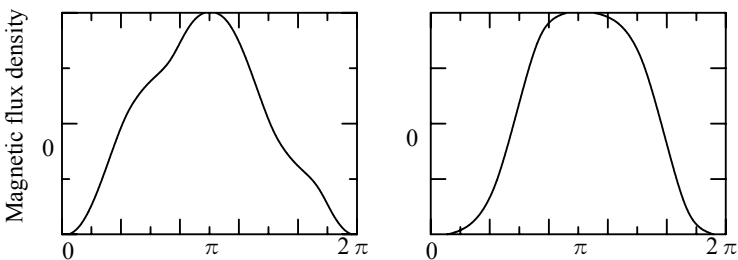

( I ) Magnetic flux waveforms

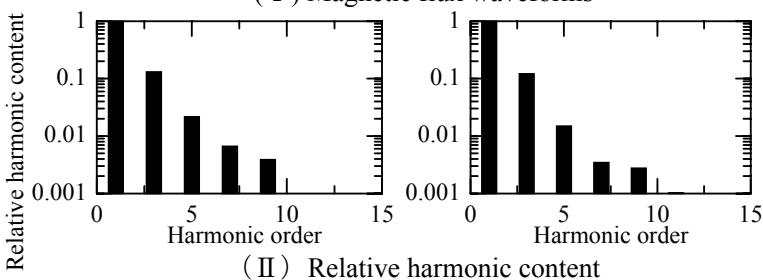

(a) Shorter magnetic path

(b) Longer magnetic path

\section{図 3 歪夕波磁束波形}

Fig. 3. The distorted magnetic flux waveforms.

相の三值 PWM 波形を使用し, 変調三角波の振幅に対する正 弦波の振幅である変調度を $50 \%$ にしたまた三角波の変調 周波数は基本波周波数の 6 倍, 16 倍, 36 倍（変調次数 6 次, 16 次，36 次）とし,鉄損特性の検討を容易にするため, 実際 に使用される PWM より低次で実験を行った。図 4 に本実験 で使用したそれぞれの理想PWM 波形と, 図 5 にそれらの調 波解析結果を示寸。図 5 より各変調次数の側帯波の高調波

（例えば変調次数 6 次の場合, 5 次と 7 次）が最も大きく重 畳していることがわかる。それらの大きさは変調次数によ らずほぼ一定になっているため，側帯波の高調波含有率の 大きさは変調度によって決まってくる。各高調波の重畳の 様子を含有率 0.1 以上でみてみると, 変調次数 16 次, 36 次

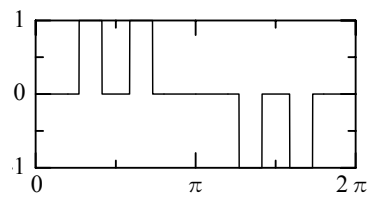

(a) Modulation order 6 th

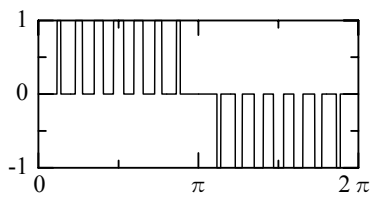

(b) Modulation order 16th

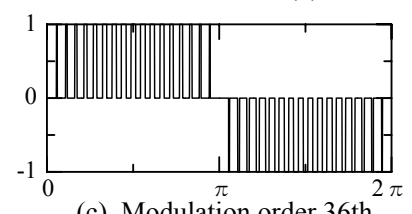

(c) Modulation order 36 th $^{2 \pi}$

図 4 対称 PWM 波形

Fig. 4. Symmetrical PWM-waveforms.
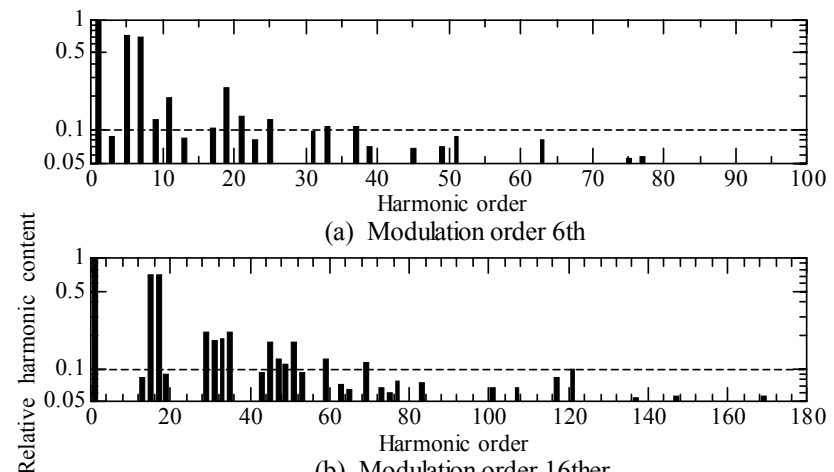

(b) Modulation order 16ther

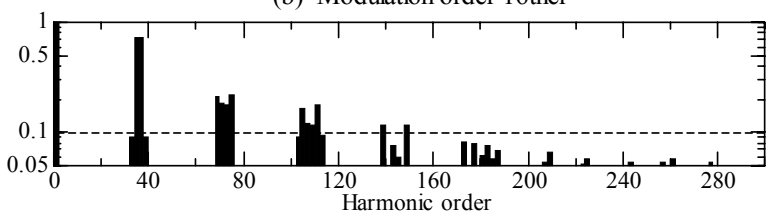

(c) Modulation order 36th

図 5 対称 PWM 波形の調波解析結果

Fig. 5. Harmonics of symmetrical PWM- waveforms.

では, 変調次数の 2 倍, 3 倍と倍周期付近の奇数次調波が大 きく重畳しており，規則性を帯びて高調波が重畳すること がわかる。しかし, 変調次数 6 次では次数が低いため, こ の規則性がくずれている。

非対称PWM 波形は図 4 の波形に直流成分を重畳させて作 成した。直流成分は対称 PWM 波形の零一ピークの振幅に対 して $5 \%$ 及び $10 \%$ 重畳させた。以降，これを直流重畳度と呼 ぶ。直流成分を重畳させても奇数次調波の高調波含有率は 対称時と変わらず，新たに直流成分と偶数調波が重畳して くる。図 6 に重畳する偶数調波の大きさを示す。各変調次 数の高調波が最も大きく重畳している。また各変調次数と もに，直流重畳度が 2 倍になると，偶数調波の大きさも 2 倍となり，比例関係であることがわかる。

測定系は図 2 の励磁装置を SST とし, 任意波形発生装置 から対称 PWM 波形及び非対称 PWM 波形を発生させ, 電力 増幅器を通して SST 内の試料を励磁する。

$\langle 2 \cdot 3\rangle$ 測定条件 基本波周波数を $50 \mathrm{~Hz}$ とし, 測定試 料は電磁鋼板（30P105 相当）及び，焼鈍済みのアモルファ スとした。試料を正弦波で励磁する場合は, 磁束密度検出 

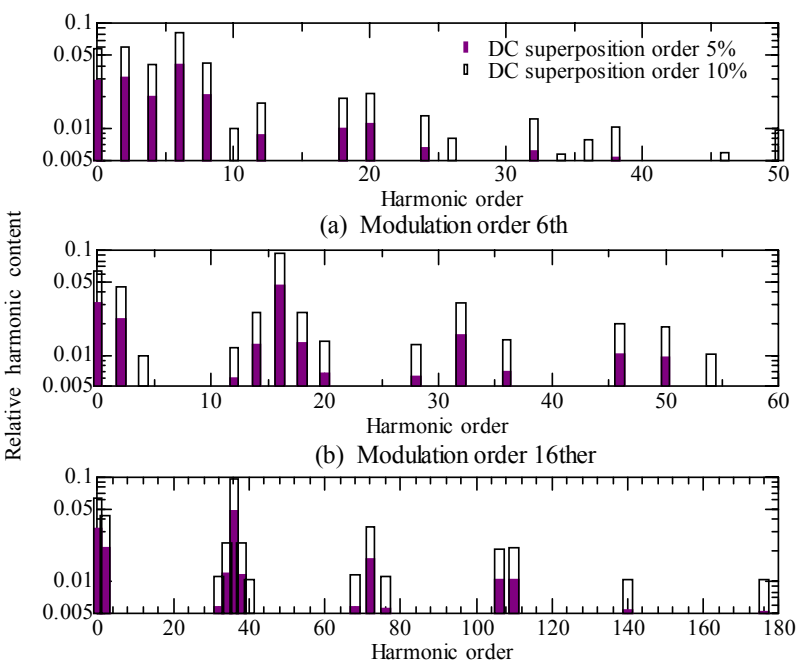

(c) Modulation order 36th

図 6 非対称 PWM 波形の偶数調波含有率

Fig. 6. An even harmonics component rate of asymmetric PWM-waveforms.

コイル（Bコイル）の誘起電圧波形が正弦波となるように, 高調波の第 9 次成分までの振幅が基本波成分の $0.5 \%$ 以下に なるまでフィードバック制御し，励磁を行った。<2・1>節で 述べた歪み波磁束でそれぞれの試料を励磁する場合，基本 波に対する高調波の含有率は，目標とする磁束波形よりほ ぼ $0.2 \%$ 以内, 高調波含有率 $5 \%$ 以上の波形で位相が 5 度以下 になるようにフィードバック制御し, 目標波形に収束した 後励磁を行っている。この時, 最大磁束密度を $0.7 \mathrm{~T}$ から $1.4 \mathrm{~T}$ 及び $1.5 \mathrm{~T}$ まで変化させるが，試料を励磁している波形率の 誤差は $1 \%$ 程度に収まっている。PWM 波励磁の場合，波形 制御は, 最大磁束密度が設定した磁束密度の值に対して士 $0.5 \%$ 以内の誤差範囲に収まるようにフィードバックを繰り 返したが，高調波の位相及び含有率の制御は行っていない。

\section{3. 測定結果及び検討}

〈3.1〉 鉄損分離 磁束正弦波条件での鉄損分離の結 果を示す。鉄損分離は， $50 \mathrm{~Hz}$ と $100 \mathrm{~Hz}$ における測定結果か ら二周波法を用いて行った。全鉄損值に対する各損失の比 率を試料毎に図 7 に示す。これよりアモルファス磁性材料 はヒステリシス損の全鉄損に対する割合が多く，渦電流損 の割合が非常に小さいことがわかる。これに対して方向性 電磁鋼板は， $1.5 \mathrm{~T}$ までは渦電流損の割合がヒステリシス損 に比べて，若干大きくなっている。また，アモルファス磁 性材料の渦電流損の割合は, 磁束密度が高くなるにつれて 増加している。方向性電磁鋼板は磁束密度が高くなると, 渦 電流損の割合は減少している。

〈3·2〉歪み波磁束下における鉄損特性 表 1 に図 3 に示した波形の最大磁束密度 $\left(B_{\max }\right)$ と実効值磁束密度 $\left(B_{e f f}\right)$ の 比率 ${ }^{(4)}$ を示す。これより, 両方の試料の励磁に用いられてい る波形がほぼ同じであることがわかる。両波形とも高調波 含有率はほとんど変わらないが，磁束密度の波形歪みであ

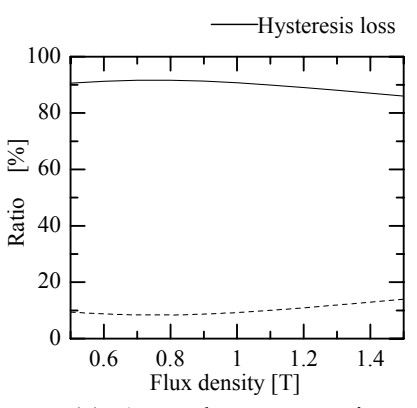

(a) Amorphous magnetic material

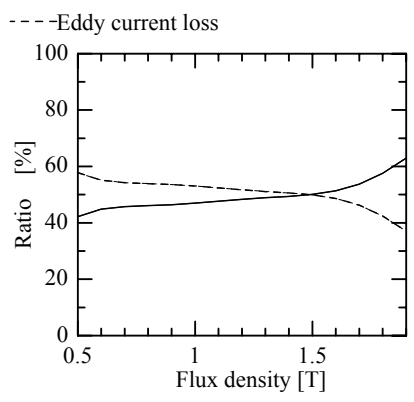

(b) Grain-oriented magnetic steel sheet
図 7 全鉄損に対する各損失の割合 $(50 \mathrm{~Hz})$

Fig. 7. Ratio of each loss to total iron loss $(50 \mathrm{~Hz})$.

表 1 歪み波磁束の $B_{\max }$ と $B_{\text {eff }}$ の比率

Table 1. Ratio of $B_{\max }$ and $B_{\text {eff }}$ of distorted waveforms.

\begin{tabular}{ccccc}
\hline Waveform & Specimen & $\mathrm{B}_{\max }$ & $\mathrm{B}_{\text {eff }}$ & $\mathrm{B}_{\text {eff }} / \mathrm{B}_{\max }$ \\
\hline Fig.3(a) & Amorphous & 1.009 & 1.017 & 1.004 \\
& Grain-oriented & 1.005 & 1.013 & 1.008 \\
Fig.3(b) & Amorphous & 1.014 & 1.207 & 1.190 \\
& Grain-oriented & 1.003 & 1.194 & 1.191 \\
\hline
\end{tabular}

る $B_{\text {eff }} / B_{\max }$ の值が変わっているのは, 高調波の位相ずれが大 きく影響しているためである。

正弦波磁束下に対する歪み波磁束下の鉄損増加率を図 8 に示す。高調波の位相のずれ方で，振幅が同じでも鉄損の 増え方も変わっていることがわかる。 $B_{\text {eff }} / B_{\max }$ の值がほぼ 1 である図 3(a)の波形励磁下では, 両試料とも正弦波磁束下で の鉄損と大きな変化はない。 $B_{\text {eff }} / B_{\max }$ が大きくなる図 3(b)の 波形励磁下では，アモルファス磁性材料の方が方向性電磁 鋼板より鉄損増加が小さいことがわかる。これは，アモル ファス磁性材料の渦電流損の割合が小さい事が原因であ る。また, アモルファス磁性材料の鉄損増加率は磁束密度 が増加するにつれて増加している。これに対し, 方向性電 磁鋼板の鉄損増加率は磁束密度が増加するにつれて減少し ている。これは渦電流損の割合がアモルファス磁性材料で は磁束密度に対して増加傾向にあるが, 方向性電磁鋼板で は減少傾向であるためと考えられる。

図 9 に最大磁束密度 $1.0 \mathrm{~T}$ における各励磁磁束波形での交 流ヒステリシスループを示す。アモルファス磁性材料の交 流ヒステリシスループの方が, 方向性電磁鋼板に比べて正 弦波からの変化が少ないことがわかる。

図 10 に各高調波鉄損の振る舞いを示寸。二つの歪み波形 は高調波の位相ずれが異なるため, 高調波鉄損の振る舞い も大きく変わっている。図3(a)の波形励磁下では, どの調波 の鉄損も正弦波磁束下の鉄損より小さくなっているが, 図 3(b)の波形励磁下では基本波鉄損が正弦波磁束下の鉄損を 上回っていることがわかる。また，高調波の鉄損を見てみ ると, 図 3 (a)の波形励磁下では, 磁束密度の増加に伴い第 3 調波鉄損は増加傾向で, 第 5 調波鉄損は減少傾向となって いるのに対して, 図 3 (b)の波形励磁下では, 第 3 調波鉄損 


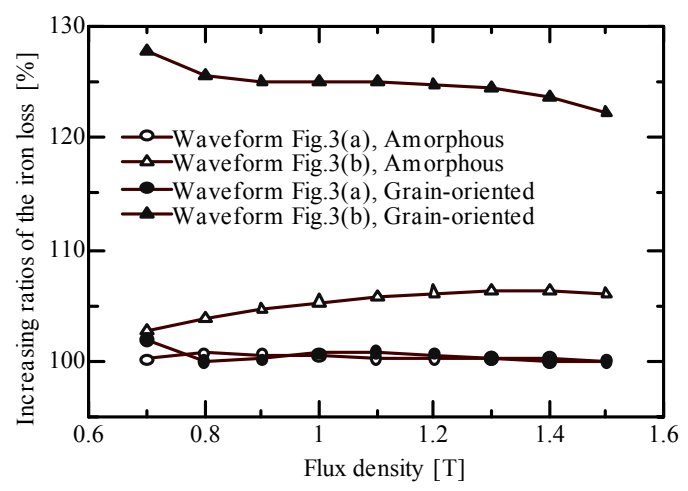

図 8 正弦波磁束下に対する歪み波磁束下の鉄損増加率

Fig. 8. The increasing ratios of the iron loss under the distorted wave flux to sinusoidal wave magnetic flux.

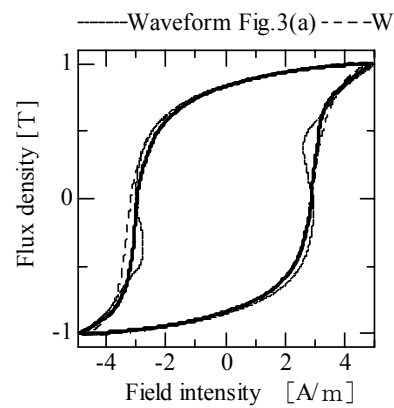

(a) Amorphous magnetic material

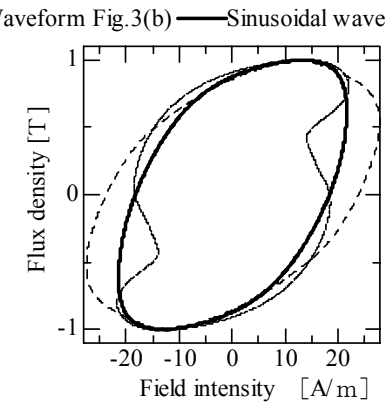

(b) Grain-oriented magnetic steel sheet
図 9 図 3(a),(b)波形励磁時の交流ヒステリシスループ (最大磁束密度 $1.0 \mathrm{~T}$ )

Fig. 9. Alternating hysteresis loop in Fig.3(a),(b) waveforms excitation $\left(B_{\max } 1.0 \mathrm{~T}\right)$.

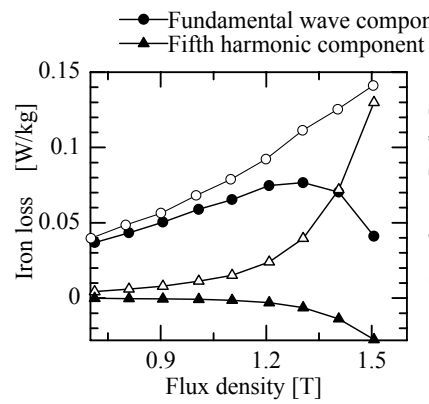

nt $\triangle-$ Third harmonic component

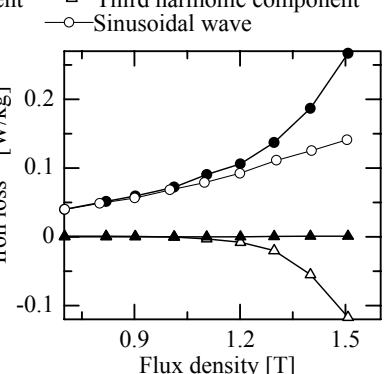

(a) Amorphous magnetic material
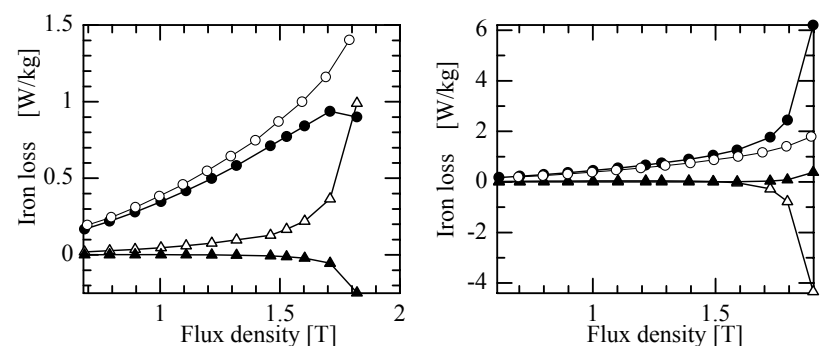

(b) Grain-oriented magnetic steel sheet

( I ) Excitation with

waveform Fig.3(a)

(II) Excitation with waveform Fig.3(b)

図 10 各高調波鉄損の振る舞い

Fig. 10. Behavior of each higher harmonic iron loss.
は減少傾向で第 5 調波鉄損は増加傾向となっている。これ は，両波形は各高調波の位相が 180 度異なるためと考えら れる。磁束密度が増加すると, 高調波の鉄損が負になる個 所があるが，これは計算上算出されたものであり，負の鉄 損が発生するわけではない。しかし両試料とも，各高調波 鉄損の振る舞いは全損失に対する渦電流損の割合に関係な く，同じ傾向を示していることがわかる。

$\langle 3 \cdot 3\rangle$ 対称 PWM 波励磁下における鉄損特性図 11 に正弦波磁束下に対する対称 PWM 波励磁下の鉄損増加率 を示す。どちらの試料も変調次数が高くなるほど, 鉄損は 小さくなっていることがわかる。これは励磁波形で, 変調 次数が高くなると重畳する高調波の次数が高くなり, B コイ ルに生じる磁束波形も正弦波に近づいていくためと考えら れる。アモルファス磁性材料は励磁波形の変調次数が変わ っても, 方向性電磁鋼板に比べて, 鉄損増加が非常に小さ いことがわかる。また, アモルファス磁性材料はどの変調 次数においても, 磁束密度が高くなるに従い鉄損増加率は 大きくなる。それに対して, 方向性電磁鋼板は, 変調次数 6 次では磁束密度が高くなるに従い, 鉄損増加率は減少傾向 になっていることがわかる。これは全鉄損に対する渦電流 損の割合が, 磁束密度が高くなると, アモルファス磁性材 料は増加していく傾向があり, 方向性電磁鋼板は減少して いく傾向があるためと考えられる。また, 方向性電磁鋼板 は変調次数が高くなると, 磁束密度によらず鉄損増加率が ほぼ一定となる傾向を示す。これは渦電流損が実効值磁束 密度の関数と仮定でき, 重畳する高調波の次数が大きくな ると実効值磁束密度が小さくなるため, 渦電流損の影響が 小さくなると考えられる。

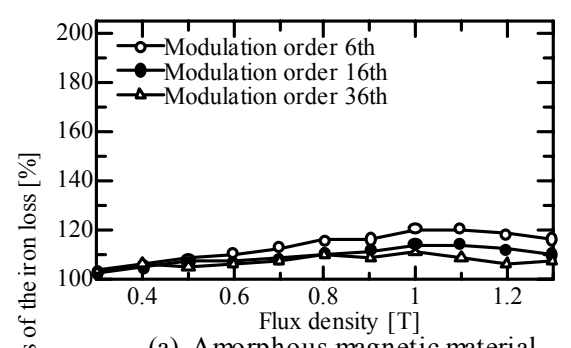

(a) Amorphous magnetic material

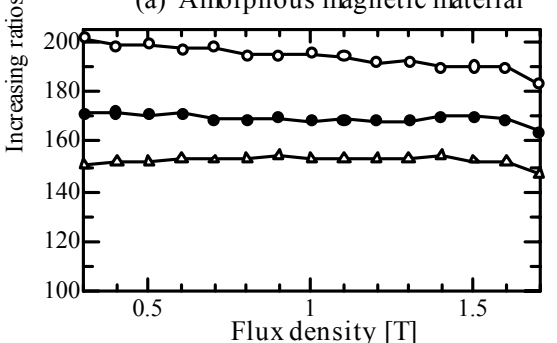

(b) Grain-oriented magnetic steel sheet

図 11 正弦波磁束下に対する対称 PWM 波励磁下の 鉄損増加率

Fig. 11. The increasing ratios of the iron loss under the symmetrical PWM-waveforms excitation to sinusoidal wave magnetic flux. 


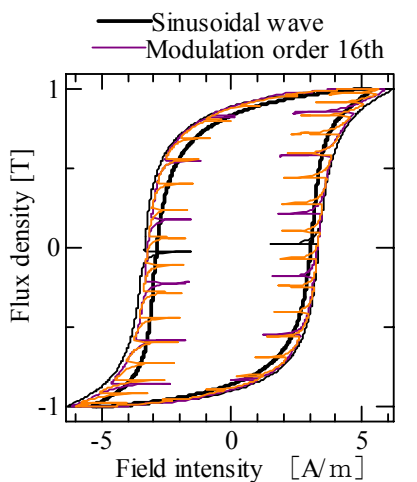
material (a) Amorphous magnetic

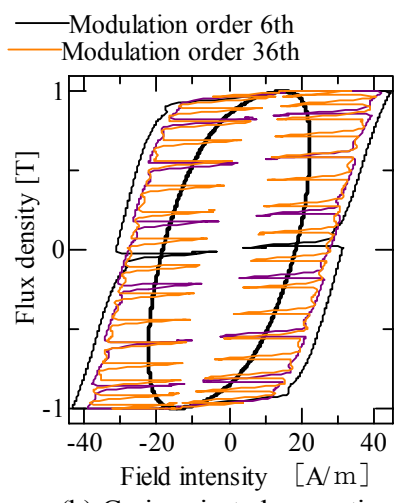

(b) Grain-oriented magnetic steel sheet
図 12 対称 PWM 波励磁の交流ヒステリシスループ (最大磁束密度 $1.0 \mathrm{~T}$ )

Fig. 12. Alternating hysteresis loop in symmetrical PWM-waveforms excitation $\left(B_{\max } 1.0 \mathrm{~T}\right)$.

図 12 に最大磁束密度 $1.0 \mathrm{~T}$ における交流ヒステリシスルー プを示す。変調次数が高くなるほど交流ヒステリシスルー プの正弦波からの膨らみが小さくなるが, 変調次数 16 次と 36 次ではほとんど変化がない。しかし，ループの窪んでい る箇所が変調次数 36 次の方が多いため, その分鉄損が小さ くなると考えられる。また，アモルファス磁性材料の交流 ヒステリシスループは, 方向性電磁鋼板に比べて正弦波か らの変化が少ないことがわかる。

〈3.4〉 非対称 PWM 波励磁下における鉄損特性 図 13 に非対称 PWM 波励磁及び対称波励磁における実測值と 理論值の $B_{\text {eff }} / B_{\text {max }}$ の比率を示す。波形が決まればどの材料で も，いかなる磁束密度でも同一になるべき值であるが，高 調波の位相及び含有率の制御を行っていないため, 両試料 で多少ばらつきが見られる。しかし，どちらの試料も変調 次数が高くなるにつれて $B_{\text {eff }} / B_{\text {max }}$ の值は小さくなっている。 これは磁束密度の波形歪みが小さくなっていることを示し ている。変調次数が 6 次の時は, 直流重畳度が大きくなる につれて, $B_{\text {eff }} / B_{\text {max }}$ の值は対称波より小さくなっていること がわかる。変調次数 16 次も同様の傾向がみられるが, 変調 次数 6 次の場合ほど大きくは変化していない。変調次数が 36 次になると, 直流重畳度の影響はほとんどみられなくな っている。理論值と測定值を比べると多少誤差はあるが, 上記と同様の傾向がでていることがわかる。直流を重畳さ せた場合, $B_{\text {eff }} / B_{\text {max }}$ の值が対称波より小さく, 一見波形歪み が小さくなっているように見えるが，これは $B_{\text {max }}$ で波形制 御しているためで, 基本波磁束密度は対称波より大きくな っており，波形歪みが小さくなっているわけではない。 $B_{\text {eff }} / B_{\text {max }}$ の值を示したのは, 両試料をほぼ同じ波形で励磁し ていることを示すためである。

図 14 に対称 PWM 波励磁下に対する非対称 PWM 波励磁 下の鉄損増加を示す。高調波の位相及び含有率の制御を行 っていないため多少ばらつきが見られるが, 両試料とも変 調次数が大きくなるほじ, 直流重畳による鉄損増加が小さ

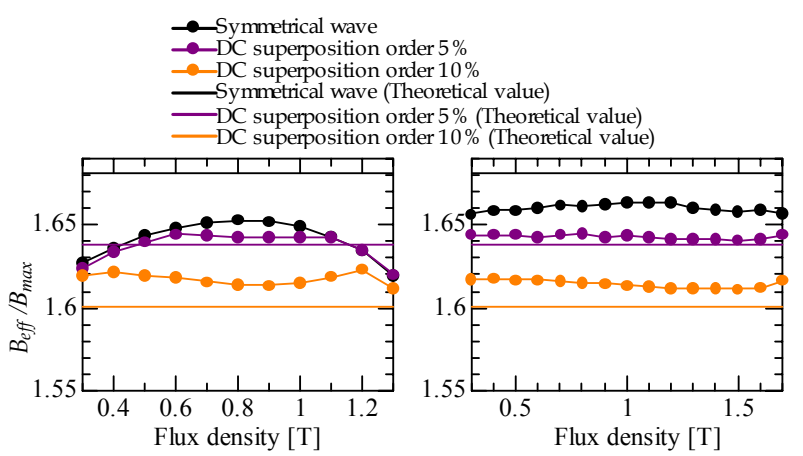

( I ) Modulation order 6th

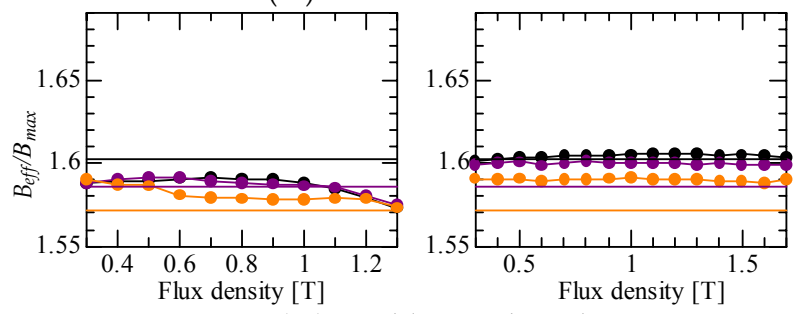

(II) Modulation order 16th

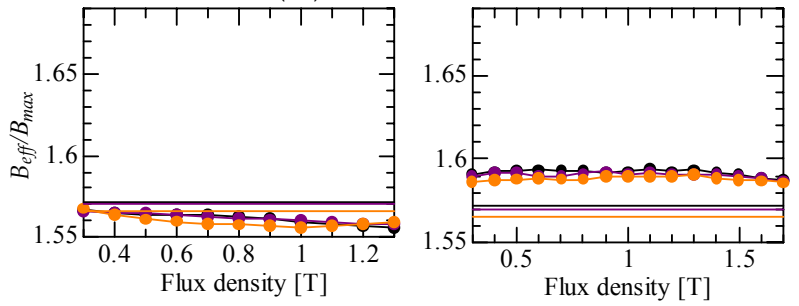

(III) The 36th modulation order

$\begin{array}{ll}\text { (a) Amorphous magnetic } & \text { (b) Grain-oriented magnetic }\end{array}$ material steel sheet

図 13 Beff/Bmax の振る舞い

Fig. 13. Behavior of Beff/Bmax.

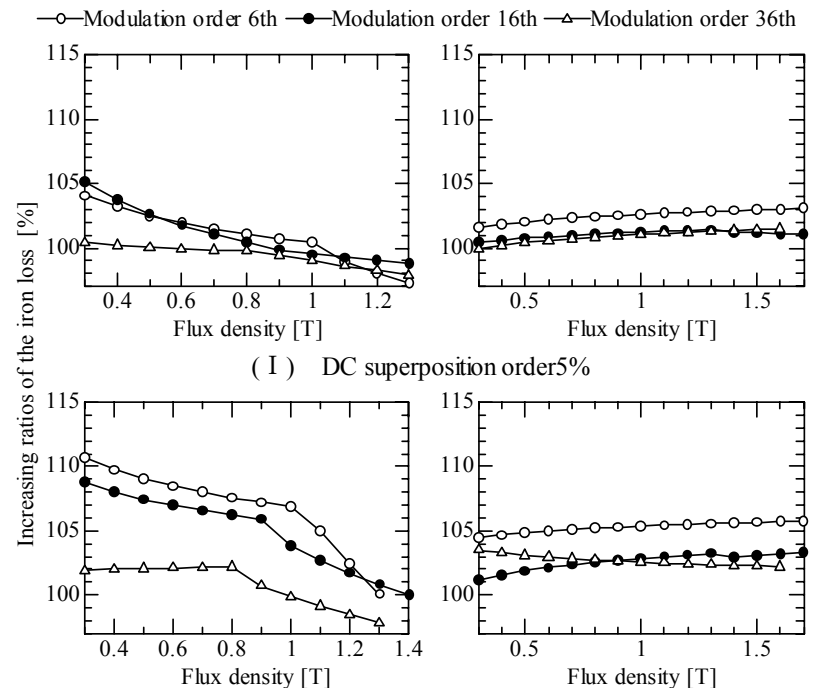

( II) DC superposition order $10 \%$

$\begin{array}{ll}\text { (a) Amorphous magnetic } & \text { (b) Grain-oriented magnetic }\end{array}$ material

steel sheet

図 14 対称 PWM 波励磁下に対する非対称 PWM 波 励磁下の鉄損増加率

Fig. 14. The increasing ratios of the iron loss under the asymmetric PWM-waveforms excitation to symmetrical PWM-waveforms excitation. 
くなっている。アモルファス磁性材料は磁束密度の増加に 伴い鉄損増加率は減少傾向を示している。それに対して方 向性電磁鋼板は磁束密度の増加に伴い鉄損増加率は増加傾 向を示している。これは, 全鉄損に対するヒステリシス損 の割合が, 磁束密度が高くなると, アモルファス磁性材料 は減少していく傾向があり, 方向性電磁鋼板は増加してい く傾向があるためと考えられる。また, 直流重畳度が大きく なると, どちらの試料も鉄損増加が大きくなっている。こ の場合の鉄損増加は, アモルファス磁性材料の方が大きい ことがわかる。これは全損失に対するヒステリシス損の割 合がアモルファス磁性材料の方が方向性電磁鋼板より大き いからと考えられる。つまり，偶数調波の影響は,ヒステリ シス損の割合に起因し, アモルファス磁性材料は偶数調波 の影響を受けやすいと考えられる。

\section{4. むすび}

本稿では, 非正弦波磁束下におけるアモルファス磁性材 料の鉄損特性の検討を行った。

比較的次数の低い高調波が重畳した歪み波磁束下及び, 多量の高調波が重畳した対称 PWM 波励磁下では, アモルフ アス磁性材料は方向性電磁鋼板より磁束正弦波に対する鉄 損増加が非常に小さいことがわかった。それに伴い，交流 ヒステリシスループの正弦波からの変化も小さくなること がわかった。これらの波形は奇数次調波だけを含み, 奇数 次調波が重畳した場合の鉄損増加は, 全損失に対する渦電 流損の割合に大きく起因してくることがわかった。

また, 対称 PWM 波励磁下に対する非対称 PWM 波励磁下 の鉄損増加は,アモルファス磁性材料の方が方向性電磁鋼板 より大きいことがわかった。このように偶数調波が重畳し た場合の鉄損増加は，全損失に対するヒステリシス損の割 合に大きく起因し，ヒステリシス損が多い材料は偶数調波 の影響を受けやすいと考えられる。これについては今後詳 しく検討するつもりである。

なお，試料など種々ご配慮いただきました新日本製鐵株 式会社の開道力氏に厚く御礼申し上げます。

(平成 14 年 9 月 20 日受付, 平成 15 年 2 月 27 日再受付)

\section{文献}

(1) S.Hori, K.Harada, Y.Ishihara, and T.Todaka : "Iron Loss Characteristics of The Amorphous Magnetic Material under the Distorted Wave Magnetic Flux", The Papers of Technical Meeting on Magnetics, IEE Japan. MAG-01-87 (2001) (in Japanese)

堀 慎一郎・原田和郎・石原好之・戸高敏之：「歪み波磁束下におけ るアモルファス磁性材料の鉄損特性」, 電気学会マグネティックス研 資, MAG-01-87 (2001)

(2) S.Hori, K.Harada, Y.Ishihara, and T.Todaka : "Iron Loss Characteristics of the Amorphous Magnetic Material under the Asymmetry PWM-waveform Excitation", The Papers of Technical Meeting on Magnetics, IEE Japan. MAG-02-86 (2002) (in Japanese)

堀慎一郎・原田和郎・石原好之 • 戸高敏之 : 「非対称 PWM 波励磁下 におけるアモルファス磁性材料の鉄損特性」, 電気学会マグネティッ クス研資，MAG-02-86 (2002) (in Japanese)

(3) S.Takada : "Magnetic Properties of Electrical Steel Sheets under PWM-waveform Excitation", 1996 National Convention Record IEE Japan, S.6-3 (1996) (in Japanese)

高田俊次 :「PWM 波励磁における電磁鋼板の磁気特性」, 平成 8 年 電気学会全国大会, S.6-3 (1996)

(4) T.Nakata, Y.Ishihara, M,Nakano : "Core Loss of Silicon Steel due to Distorted Wave Flux”, J.IEE Japan, Vol.90, No.1, p.115 (1970-1) (in Japanese)

中田高義・石原好之・中野正典：「ひずみ波磁束によるけい素鋼板の 鉄損」, 電学誌, 90, 1, p.115 (1970-1)

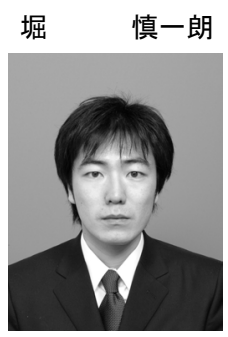

（学生員）平 13 同志社大 $\cdot$ 工・電気卒。現在 同大大学院工学研究科博士前期課程在学中。 （現・日本電気株式会社勤務）

原 田 和 郎

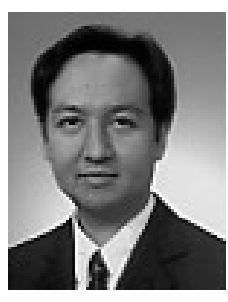

石原好之

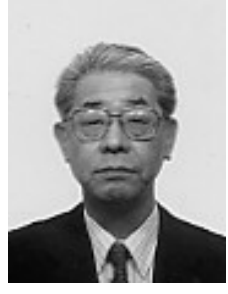

戸 高 敏 之

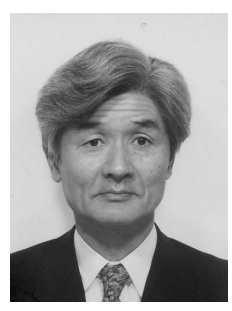

（正員）昭 61 九大 -工・電気卒。平 3 同大大 学院工学研究科博士後期課程修了。同年同志社 大 $\cdot$ 工 $\cdot$ 助手, 平 4 同専任講師, 平 8 同助教授, 現在に至る。工博。主として, スイッチングコ ンバータ・インバータの高効率化, 低ノイズ化 に関する研究に従事。

（正員）昭 39 同志社大 -工・電気卒。同年岡 山大 $\cdot$ 工 助手, 講師, 助教授を経て, 昭 56 同志社大助教授, 昭 60 同大教授, 現在に至る。 工博。主として, 電気機器鉄心の磁気特性に関 する研究及び太陽光発電システムに関する研 究に従事。

（正員）昭 36 同志社大 -工・電気卒。昭 38 同 大大学院工学研究科修士課程修了。同年同大 $\cdot$ 工・助手, 昭 56 同教授, 現在に至る。工博。 主として, 磁気応用に関する研究に従事。 